•综述・

\title{
红外相机技术在物种监测中的应用及数据挖掘
}

\author{
刘雪华 $1^{*}$ 武鹏峰 $^{2}$ 何祥博 $^{3}$ 赵翔宇 ${ }^{1}$ \\ 1 (清华大学环境学院生态学教研所, 北京 100084) \\ 2 (沈阳师范大学生命科学学院, 沈阳 110034) \\ 3 (陕西佛坪国家级自然保护区，陕西佛坪 723400)
}

\begin{abstract}
摘要: 由于濒危物种数量稀少以及大多数野生动物对人类活动敏感, 增加了传统调查的难度。众所周知, 红外相 机在野生动物调查研究中具有天然优势; 然而随着红外相机技术的广泛推广应用及数据采集量的不断加大, 科研 人员也面临了一系列关于红外相机监测及后续数据处理中出现的问题。本文详细阐述了红外相机数据管理和利用 方面存在的 3 个关键问题: 数据管理缺乏规范化、数据网络缺乏一体化、数据获取缺乏标准化。同时以秦岭、卧龙 等地的一些研究为主体, 列举分析了红外相机照片后续数据挖掘中 8 个方面的内容, 即兽类的个体识别、物种时间 活动格局、物种空间活动格局、偶见物种信息利用、物种行为活动、繁殖信息、疾病情况、人为干扰。这些信息 的有效利用可为野生动物及生物多样性的保护、管理提供一定科学支撑。
\end{abstract}

关键词: 红外相机; 监测; 数据挖掘; 生物多样性; 野生动物; 保护

\section{Application and data mining of infra-red camera in the monitoring of species}

\author{
Xuehua Liu ${ }^{1 *}$, Pengfeng $\mathrm{Wu}^{2}$, Xiangbo $\mathrm{He}^{3}$, Xiangyu Zhao ${ }^{1}$ \\ 1 Division of Ecology, School of Environment, Tsinghua University, Beijing 100084 \\ 2 College of Life Science, Shenyang Normal University, Shenyang 110034 \\ 3 Foping National Natural Reserve, Foping, Shaanxi 723400
}

\begin{abstract}
Wildlife population is low and most of them are very sensitive to human disturbing, which makes traditional survey difficult. As known, infra-red camera technology has many advantages in wildlife study. However, with its wide application and increased data amount, researchers are facing some problems concerning infra-red camera monitoring and later data processing and analyzing. This paper describes in details three key problems on infra-red camera data management and use, such as lacking standardization, integration and normalization. The present paper also lists and analyzes eight aspects about photo data mining, based on researches carried out in the Qinling Mountains, Wolong Nature Reserve, etc. It involves individual recognition, temporal/spatial activity pattern, information-extracting of occasional species, behavior and reproduction, disease situation and interference by humans. If all this information can be used effectively, we hope to provide scientific support at some extent on wildlife and biodiversity conservation and management in future.
\end{abstract}

Key words: infra-red camera; monitoring; data mining; biodiversity; wildlife; conservation

构建系统的监测体系、开展长期的野外监测是 实现保护生物多样性的基础, 也是评估生物多样性 保护成效的有效途径(马克平，2011)。对野生动物 进行长期监测是中国森林生物多样性监测网络
(Chinese Forest Biodiversity Monitoring Network, CForBio)等大尺度生物多样性监测研究计划的一个 重要组成部分。2009年以来, CForBio网络陆续在10 个森林动态监测样地开展了利用红外相机来监测

收稿日期: 2018-02-11; 接受日期: 2018-07-13

* 通讯作者 Author for correspondence. E-mail: xuehua-hjx@mail.tsinghua.edu.cn 
野生动物多样性的研究(肖治术, 2014)。野生动物多 样性是生物多样性监测与保护管理评价的关键指 标(蔡玉生等, 2016)。

由于濒危物种数量稀少以及大多数野生动物 对人类活动敏感, 而且某些野生动物的生态习性如 警觉、行踪隐蔽、夜间活动等, 都增加了传统调查 的难度。红外相机具有全天候无间断、隐蔽性强、 非损伤性、较少受到环境条件和研究人员的限制等 特征, 在野生动物调查研究中具有天然优势, 且红 外相机安放样点可根据具体研究对象有选择地进 行布置(贾晓东等, 2014)。国外使用红外相机开展野 生动物调查研究已有较长的历史, 最早的报道见于 Champion (1927)。该技术在20世纪90年代逐渐发展 成熟, 研究内容涵盖生态学、种群评估、行为生态 学、兽类资源调查以及动物损害、动物种群数量和 密度的研究等领域(Carthew \& Slater, 1991; Harris, 1995; Martorello et al, 2001; Karanth et al, 2004; Rowcliffe \& Carbone, 2008)。2017年, 国际刊物 Remote Sensing in Ecology and Conservation出版了 一期关于红外相机技术应用的专辑(Key Frontiers in Camera Trapping Research) (Rowcliffe, 2017)。该专 辑有 3 篇综述文章、1篇研究文章和 1 篇展望文章, 内 容涵盖了野生动物保护、动物活动格局、模型及相 关软件。

我国使用红外相机技术进行相关研究的工作 始于记录野生动物的活动模式(裴家骐，1998)和多 样性(马世来和Harris, 1996; Li et al, 2010), 或者记 录特定的野生动物, 如东北虎 (Panthera tigris altaica) (李志兴, 2004; 李冰等, 2008)、大熊猫 (Ailuropoda melanoleuca) (卢学理等, 2005; 何佰锁 等, 2009)、雪豹(Panthera uncia) (马鸣等, 2006; 马 鸣和徐峰, 2006)及华南虎(Panthera tigris amoyensis) (黄祥云等, 2003, 2004)等。据不完全统计, 目前我国 各地通过红外相机所记录的兽类已超过 100 种，鸟 类已超过150种, 充分显示了运用红外相机技术调 查兽类和地栖性鸟类本底资源的优势(李晟等, 2014)。我国也相继出版了两个关于红外相机技术应 用推广的专辑: 2014年《生物多样性》组织了一期 专辑, 有17篇关于生物编目的文章, 调查了一些森 林动态样地和保护区的物种本底; 2016年《兽类学 报》也专门组织了一期基于红外相机调查技术的自 然保护区野生动物资源编目专辑。然而, 专辑内容
还基本停留在物种编目方面，对于该技术的问题、 数据分析方法及信息挖掘还需要投入科研力量。

\section{红外相机应用中存在的主要问期}

随着我国在生态保护上的投入加大，应该可以 说所有保护区都在应用红外相机进行生物多样性 监测。但如何规范管理高速增长的图像数据, 如何 增加数据的共享性, 以及如何更大程度地挖掘照片 中所包含的有用信息，显得尤为重要，也是普遍存 在的问题。

\section{1 图像数据量增长迅速, 数据管理缺乏规范化}

近5年来，红外相机技术在我国各级自然保护 区的应用发展十分迅猛，据不完全统计，已投入的 红外相机累计超过2万台(肖治术, 2016)。保守估计1 台红外相机连续工作 1 年至少可以拍摄到 200 张有 动物的有效照片, 各个监测样区所获得的图像正在 以万为单位进行累积(肖治术等, 2014b)。如清华大 学刘雪华团队从2009年开始在秦岭南坡开展红外 相机监测，陆续安装红外相机近200台，集中分布 于佛坪、观音山、长青等几个保护区，截止到2018 年共获取有效野生动物照片约10万张。红外相机的 优势之一就是图像数据便于存档和检索(O’Connell et al, 2011)。庞大的图像数据需要建立规范的数据 库, 统一存档管理, 方便以后调用和查看。同时, 相 机位点的信息(包括相机工作情况、生境信息等)也 需要同步建立数据库进行管理。

在数据库建设方面, 国内外已有成功案例。如 热带生态评价与监测网络 (TEAM Network, http://www.teamnetwork.org/) 可用于管理和分析红 外相机所获取的图像数据。TEAM Network于 2007 年起已在南美洲、非洲、亚洲等地的16个热带森林 监测样地执行, 其中包括了世界热带森林研究中心 (Center for Tropical Forest Science)设置的多个森林 动态监测样地所在区域。美国史密森研究院和北卡 罗莱纳州立大学于 2013年合作建立的网络数据信 息平台 (eMammal, http://emammal.si.edu/), 主要通 过红外相机技术来记录和收集美国和全球其他区 域的兽类数据。

国内监测网络的建设相对缓慢, 中国科学院动 物研究所于 2013年组织研发了基于野生动物红外 相机监测的图像数据管理系统 (Camera Data, http://cameradata.ioz.ac.cn)。如前所述，2009以来陆 
续有 10 个森林动态监测样地采用红外相机技术来 监测兽类和地面活动鸟类的多样性, 且监测数据都 上传至Camera Data系统。中国生态系统类型丰富, 地域辽阔, 分类型分区域的数据库都应该考虑建设, 但现在的投入仍很缺乏。

\section{2 数据资料共享性差, 数据网络缺乏一体化}

当前许多研究集中于某个保护区(或保护地)进 行(施小刚等, 2017; 章书声等, 2017), 只有部分研 究扩展到区域尺度(Li et al, 2012; 林㻦璇, 2016 ${ }^{\circledR}$; 吕子欣, 2016 ${ }^{(2)}$; 刘凯等, 2017)。如刘凯等(2017)利用 红外相机技术对皖南山区8个省级以上自然保护区 的兽类资源进行了调查。清华大学团队 (林㻦璇, $2016^{(1)}$; 吕子欣, $2016^{(2)}$ )对秦岭南坡3个保护区的兽 类和鸟类进行了红外相机监测, 并研究了不同森林 恢复模式对野生动物生境利用的影响。但由于数据 管理和分析平台建设不完善, 或数据共享机制还不 健全, 已收集的数据大部分分散在各个保护区或者 研究者手中。

依托标准化的红外相机监测平台, 结合生态学 模型与统计方法, 就可以通过长期连续的监测, 评 估动物群落的总体动态变化。目前已经建立起若干 红外相机监测研究网络, 如北京大学、北京师范大 学、中国林业科学研究院等高校和科研院所建立了 一些基于红外相机技术的区域性兽类监测专项网 (Li et al, 2010; 李戬等, 2014; Wang et al, 2017)。清 华大学也建立了秦岭野生动物监测数据库。但这些 网络之间在方案设计、调查规程、数据格式等方面 都不尽相同, 在一定程度上限制了数据与信息的共 享和进一步应用。2013年Camera Data系统成功运行 后，许多研究者陆续把各自的监测数据都上传至网 络系统, 一定程度上增加了数据的共享性(胡力等, 2016; 薛茂盛等, 2016)。

中国兽类多样性监测网是2010年由中国科学 院发起建立的全国性的生物多样性监测与研究网 络, 经过6年的发展在全国陆续建立了兽类监测样 区30余个(肖治术等, 2017)。自2016年起, 在环境保 护部的支持下, 环境保护部南京环境科学研究所牵 头并组织全国各科研院所、高等院校、保护区等相

(1) 林㻦璇 (2016) 不同干扰机制下秦岭鸟类多样性及活动特征研究. 清华大学本科毕业论文, 北京.

(2) 吕子欣 (2016) 不同干扰机制下秦岭兽类多样性及活动特征研究. 清华大学本科毕业论文, 北京.
关单位和部门开展了全国大中型哺乳动物红外相 机观测网络(China BON-Mammals)的建设工作, 逐 渐形成覆盖全国的大中型哺乳动物多样性观测网 络(李佳琦等, 2018), 并建立了基于红外相机技术的 监测数据库管理规范与分析标准。建立平台或网络 间信息共享机制，加强各研究团队和单位之间的合 作交流，推动不同区域、不同单位之间的数据共享， 将有力地促进我国相关领域整体研究水平的快速 提升。

\section{3 数据信息挖掘远不充分, 数据获取缺乏标准化}

红外相机数据的应用主要涉及如下几个方面, 即多样性调查、行为学研究、种群数量和分布、方 法学研究(张履冰等, 2014)。学者们围绕前 2 个方面 做了许多工作，提出了一系列指数来评价动物多样 性及活动规律，如丰富度指数(relative abundance index, Rowcliffe et al, 2014)、温度活动强度指数 (temperature activity intensity index, 唐卓等, 2017a, b)、月相活动强度指数(lunar-phase activity intensity index, 唐卓等, 2017b)等。在种群参数估计方面，目 前主要有种群密度估计模型和种群空间分布占据 率模型，而种群密度估计可进一步划分为具有天然 标记的“捕获-重捕获”模型，和不具天然标记的“相 机一个体随机相遇”模型。李勤等(2013)详细介绍了 上述3类模型的基本原理、发展过程、统计假设及 使用范围。“捕获-重捕获”模型在基于动物个体识别 的分析中已经得到了成功的应用(Karanth \& Nichols, 1998; Royle et al, 2009), 但大多数物种无法通 过照片进行个体识别。Rowcliffe等(2011)优化了随 机相遇模型，量化了动物触发相机的概率随着距离 的增加而降低的程度。清华大学刘雪华团队在2013 年试验性地建立了一个粗浅模型，主要是基于一定 空间范围内某物种出现率而对种群数量进行动态 性估算(Liu et al, 2013)。另外, O’Brien等(2010)提出 了野生动物图片指数(wildlife picture index), 在群 落水平上评估野生动物变化趋势。

监测方案的不统一是限制数据区域间比较的 关键因素。如包欣欣和刘丙万(2018)在黑龙江凉水 保护区和丰林保护区典型红松林监测样地, 进行林 下鸟类和兽类的初步监测，设置了 30 个红外相机监 测点，每个监测点覆盖面积为2 ha; 张源笙等(2017) 在北京松山国家级自然保护区调查时，设置了 384 个位点, 每个监测点覆盖面积约为 $12.16 \mathrm{ha}$ 。肖治术 
等(2014a)基于我国森林动态监测样地红外相机监 测的进展情况, 提出了我国森林野生动物红外相机 监测的规范和注意事项。目前CForBio网络已有 10 个样地开展了野生动物红外相机监测, 初步建立和 执行了公顷网格(或公里网格)的监测方案。

\section{红外相机数据信息的多方面挖}

红外相机在我国早期应用阶段, 照片数据多数 用于动物多样性调查和编目整理, 近两三年来, 研 究内容逐渐向深度及广度发展。数据管理过程中, 尽可能提取图像中所有信息(如时间、地点、动物), 有的红外相机还能提供一些基本环境信息, 如温度 (刘小斌等, 2017; 唐卓等, 2017a)、月相(唐卓等, 2017b)等指标, 可以用于分析野生动物对环境因子 的需求及其生态位。通过对收集整理的信息进行分 析, 可以更大程度挖掘出关于野生动物物种甚至种 群的信息，包括：(1)大型兽类的个体识别; (2)区域 野生动物物种在时间上的活动格局; (3)物种在空间 上的活动格局; (4)偶见物种的红外相机信息利用; (5)野生动物的各种行为分析(包括取食关系); (6)野 生动物的繁殖信息挖掘; (7)野生动物疾病情况监测; (8)人为活动干扰信息提取等等。长期的红外相机监 测可以让我们挖掘出许多有科学价值的信息, 为生 物多样性的深入研究和保护提供夯实的科学支撑。

\section{1 大型兽类的个体识别}

应用红外相机技术进行个体识别, 主要是在猫 科动物这一类群有广泛的应用(Karanth \& Nichols, 1998; Heilbrun et al, 2003; Royle et al, 2009)。因为每 只个体身体上的斑纹形状及其排列关系具有特异 性，通过对比其身体相同部位的斑纹，每只个体都 能得到准确的识别(Hiby et al, 2009)。如马鸣等 (2006)对新疆天山雪豹的识别。除了自然斑纹外, 部 分人为标志 (耳标、颈圈的编号等)也可以作为识别 特征(Martorello et al, 2001)。在个体识别时, 有一系 列软件可以使用, 如Extract Compare、Fast Stone Image Viewer等。Extract Compare软件基于三维建模, 通过对比图片信息的相似度来得到数据库中两两 体侧花纹的相似系数。该方法快捷、准确性高、操 作简单, 适合大样本量数据库的个体识别与分析, 如李治霖等(2014)基于这一技术对东北虎和东北豹 (Panthera pardus orientalis)进行了个体识别。

\section{2 区域野生动物物种在时间上的活动格局}

(1)总体活动格局。在特定区域空间范围内, 使 用一定量的红外相机开展超过一个年度的监测, 所 获得的相机照片进行信息整理后，可以获得整个监 测区域的所有物种(武鹏峰等, 2012)、某个类群物种 (如有蹄类) (贾晓东等, 2014)或单个物种如野猪(Sus scrofa)、雪豹(王长平等, 2015; 唐卓等, 2017b)在年 度空间里(平均情况)的总体活动格局，或在不同年 度(Liu et al, 2013)的总体活动格局。可以看出, 总体 来说绝大多数物种是夏季最活跃, 春季和秋季其次, 冬季最不活跃，不同年度可能会因气候变化而产生 差异。但不同物种因对环境条件的需求不同而呈现 出时空差异性，如野猪在观音山保护区在初冬和晚 夏的活动格局相似，雪豹在卧龙保护区呈现冬季高 活跃性(唐卓等, 2017b)。

(2)季节活动及日活动规律。红外相机记录了照 片的拍摄时间，这些信息可以用来开展更细致深入 的动物活动格局分析。在这些分析中，可以得到物 种在春、夏、秋、冬四季的不同活动格局及日活动 格局，还可以就同域物种、不同性别进行对比分析， 如唐卓等(2017a)利用挖掘的红外相机信息对卧龙 的绿尾虹雉(Lophophorus lhuysii)活动行为进行了深 入的研究, 结果表明雄性绿尾虹雉的活动较䧳性更 集中于早晚高峰，且早高峰晚于雌性。

\section{3 物种在空间上的活动格局}

物种在空间上的活动格局体现在不同物种对 生境的选择和利用。通过合理布样来获取红外相机 照片数据, 可反映不同物种的生境需求, 或同一物 种的多个生境需求。清华大学研究团队在秦岭于 2009年起开展了不同生境类型下野生动物的红外 相机监测研究, 虽然是秦岭森林中的同域动物, 但 对生境的选择和喜好(即出现频率)是不同的(Liu et al，2017)。该团队还对秦岭未砍伐森林及砍伐后不 同恢复方式的森林进行了动物活动监测(林㻦璇, $2016^{(1)}$; 吕子欣, $2016^{(2)}$ ), 发现了人工林被一些物种 如野猪、毛冠鹿(Elaphodus cephalophus)、金钱豹 (Panthera pardus)等所偏好; 而次生林中的兽类和 鸟类种类均少。龙华等(2017)利用生态位重叠指数

(1)林㻦璇 (2016) 不同干扰机制下秦岭鸟类多样性及活动特征研究. 清 华大学本科毕业论文, 北京.

(2)吕子欣 (2016) 不同干扰机制下秦岭兽类多样性及活动特征研究. 清 华大学本科毕业论文, 北京. 
(niche overlap index)计算了 4 种偶蹄类间的资源利 用重叠程度。

\section{4 偶见物种的红外相机信息利用}

有些兽类物种因种群数量小而少见, 如秦岭的 金钱豹、金猫(Catopuma temminckii)、大灵猫(Viverra
zibetha)、黄腹鼠(Mustela kathiah)等，长期的红外相 机监测可以拍摄到这些偶见物种的照片, 从而为挖 掘信息和分析个体活动以及分析种群情况提供了 强有力的支持。照片显示金钱豹白天和晚上都有活 动，人工林和天然林都有利用(图1a，b)，但根据拍
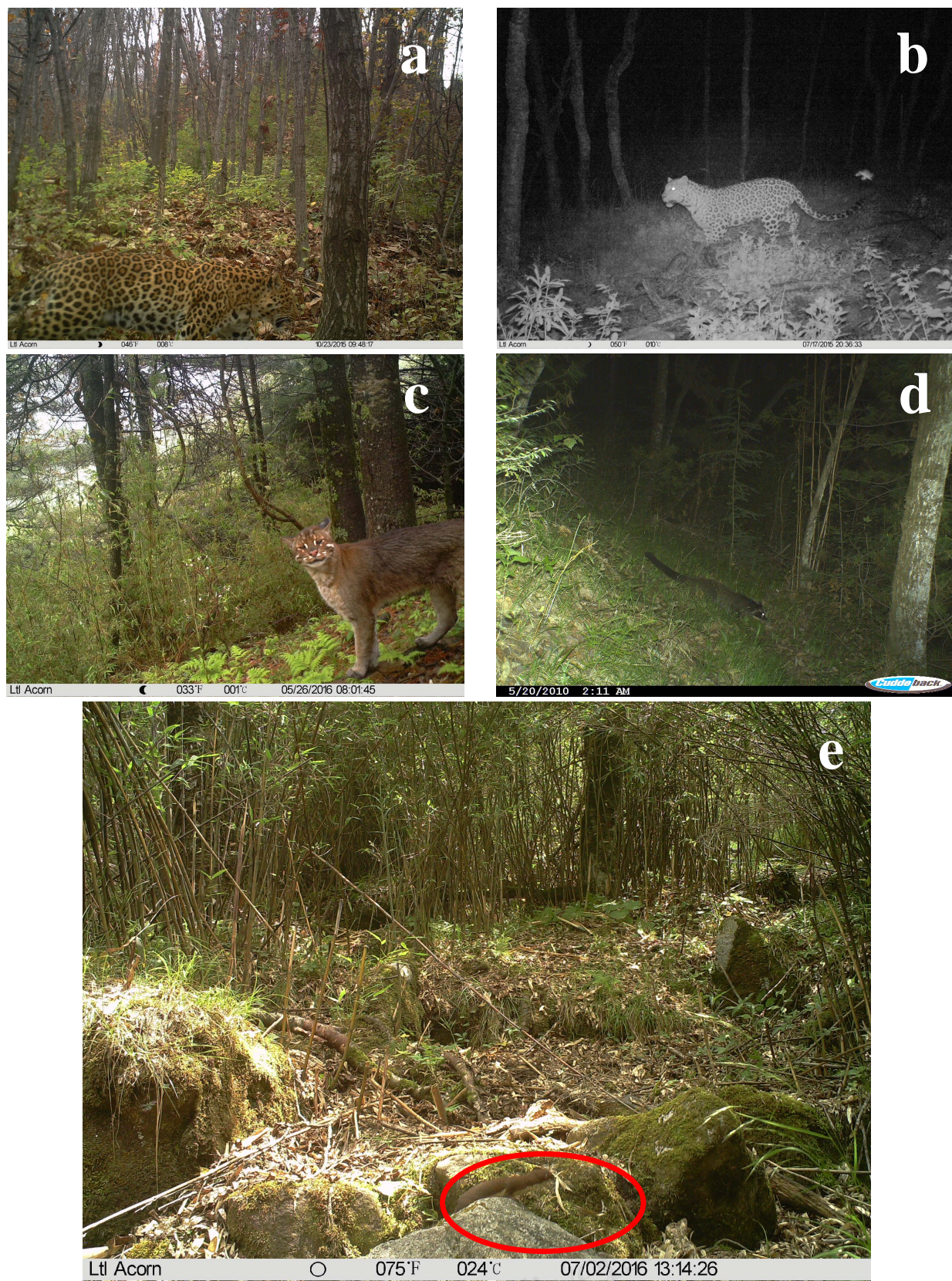

图1 偶见物种的红外相机照片(清华大学刘雪华提供)。(a)金钱豹(2015-10-23秋季秦岭梁落叶松林); (b)金钱豹(2015-07-17夏 季光头山天然林); (c)金猫(2016-05-26长青云杉林山脊); (d)大灵猫(2010-05-20观音山落叶松林); (e)黄腹鼠(2016-07-02佛坪保 护区光头山)

Fig. 1 The rare species captured by infrared cameras. Photos are provided by Xuehua Liu from Tsinghua University. (a) Panthera pardus (Larch forest in Qinling Mountain in autumn, 2015-10-23); (b) Panthera pardus (Natural forest in Guangtoushan Mountain in summer, 2015-07-17); (c) Catopuma temminckii (Ridge of spruce forest in Changqing Nature Reserve, 2016-05-26); (d) Viverra zibetha (Larch forest in Guanyinshan Nature Reserve, 2010-05-20); (e) Mustela kathiah (Guangtoushan Mountain in Foping Nature Reserve, 2016-07-02) 
摄频率，在人工林出现频率更高。金猫在红外相机 监测时间段(2009-2017)内只拍摄到1次(图1c), 可 见金猫在秦岭的种群数量很少。大灵猫(图1d)和黄 腹鼣(图1e)也和金猫是同样的情况，均只拍摄到1次, 种群数量少。这些信息对于更新区域动物编目及制 定合理保护措施有支持作用。
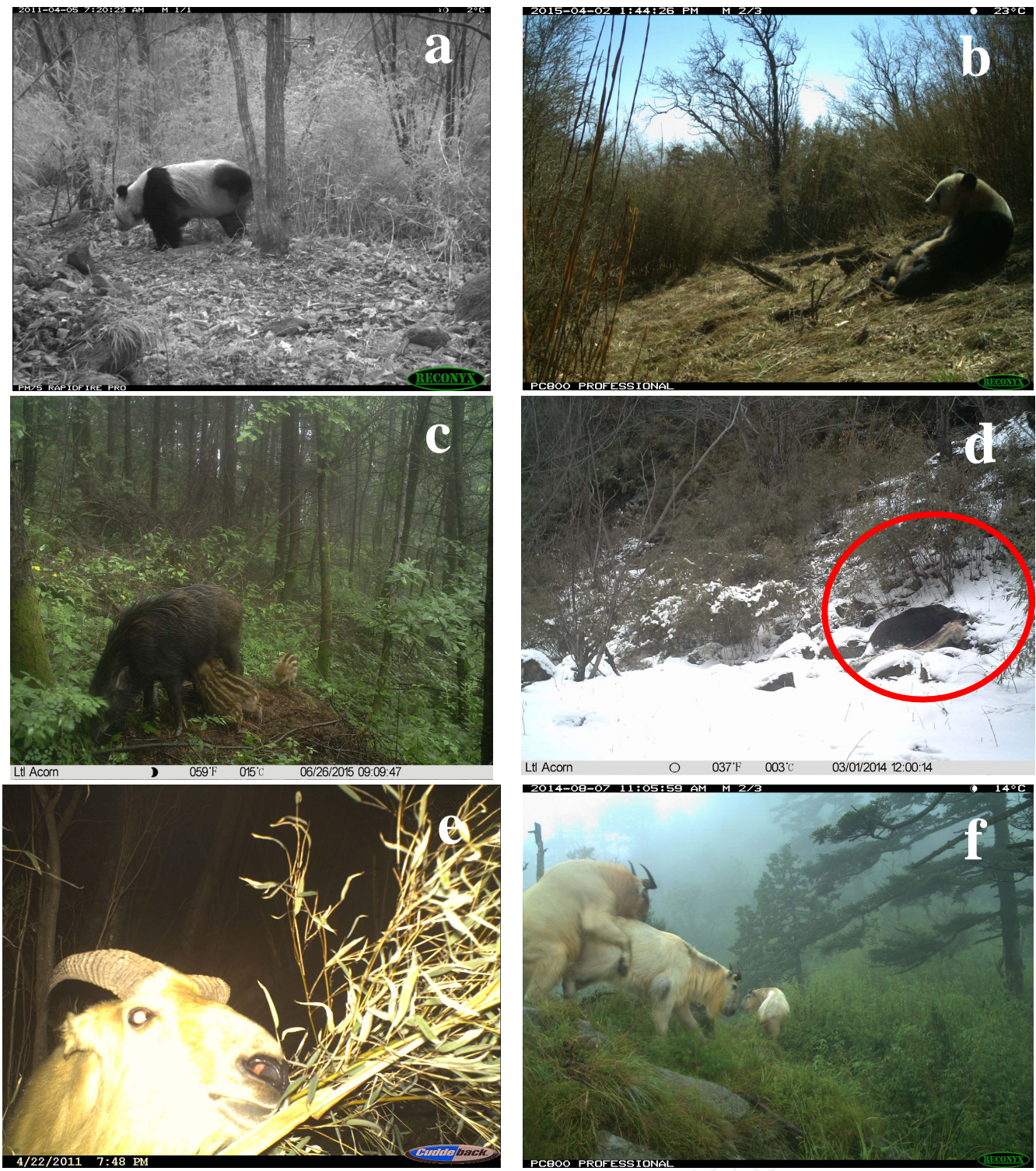

图2 红外相机捕捉到的野生动物行为(a-c 和e-f由清华大学刘雪华提供, d由观音山保护区和清华大学共同提供)。(a)大熊猫 做气味标记(2011-04-05观音山西沟); (b)大熊猫晒太阳(2015-04-02佛坪光头山); (c)野猪小崽吃奶(2015-06-26长青落叶松林); (d)野猪拖拉羚牛尸体(2014-03-01观音山保护区); (e)羚牛取食竹子(2011-04-22观音山保护区); (f)羚牛交配行为(2014-08-07佛 坪光头山)

Fig. 2 Activities of wild animals captured by infrared cameras. Pictures a, b, c, e and $\mathrm{f}$ are provided by Xuehua Liu from Tsinghua University, and picture d from Guanyingshan Nature Reserve and Tsinghua University. (a) Scent marking by pandas (Xigou Valley in Guanyinshan Nature Reserve, 2011-04-05); (b) Panda basking (Guangtoushan Mountain in Foping County, 2015-04-02); (c) Cub of wild boar sucking (Larch forest in Changqing Nature Reserve, 2015-06-26); (d) Wild boar with dragging corpse of takin (Guanyinshan Nature Reserve, 2014-03-01); (e) Takin eating bamboo (Guanyinshan Nature Reserve, 2011-04-22); (f) Takins mating (Guangtoushan Mountain in Foping County, 2014-08-07) 
(Budorcas taxicolor) 户体、羚牛取食竹子及交配等。 如果没有红外相机照片记录, 很难了解到野生动物 在野外的一些特殊行为。当监测时间够长、红外相 机数据量够大时, 就可对物种的行为进行归纳和统 计分析。如王长平等(2015)和唐卓等(2017a)就利用 多年的红外相机照片数据分别对野猪、绿尾虹雉的 各种行为进行了统计分析; 贾晓东等(2014)利用红
外相机技术分析了秦岭有蹄类动物活动行为差异性。

\section{6 野生动物种群的繁殖及发展信息挖掘}

红外相机照片数据还可以为我们提供不同年 度某种野生动物的种群繁殖及发展信息, 如羚牛的 亚成体和幼体数(图3a中有亚成体)及羚牛群(图3b 中有成体、亚成体及多个小崽)、野猪小种群个体数 (图3c中有6只野猪)和小崽数(图2c中有1只雌性成体
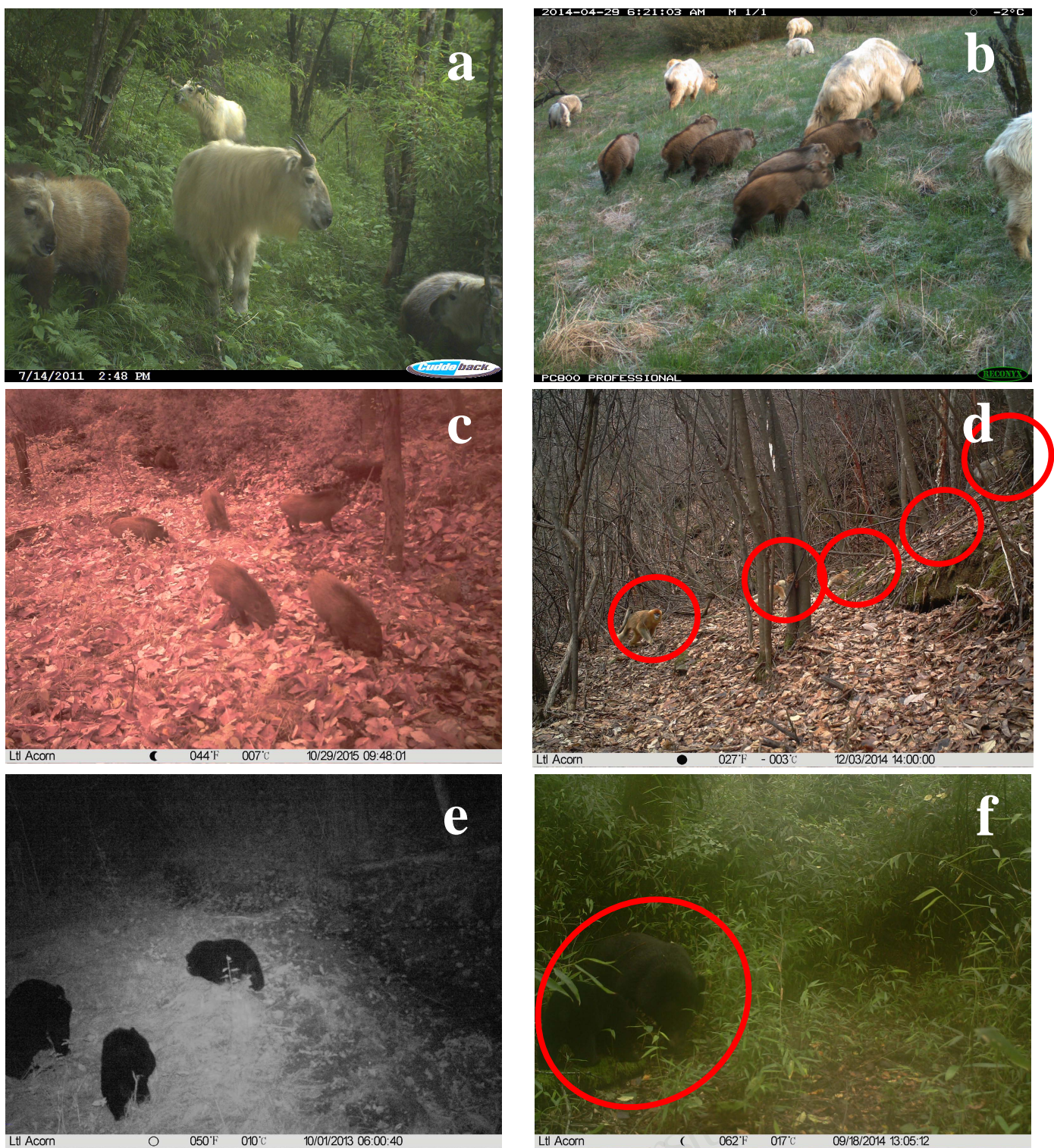

图3 红外相机获取的野生动物种群繁殖信息(清华大学刘雪华提供)。(a)羚牛亚成体和幼体(2011-07-14佛坪观音山); (b)羚牛 群(2014-04-29佛坪观音山); (c)野猪小种群(2015-10-29佛坪保护区东沟); (d)金丝猴群(2014-12-03佛坪观音山寸沟); (e)黑熊家 庭(2013-10-01佛坪东沟); (f)黑熊母子(2014-09-18佛坪西河跃湾沟)

Fig. 3 Propagation information of wild animals captured by infrared cameras. Photos are provided by Xuehua Liu from Tsinghua University. (a) Sub-adult and cub of takin (Guanyinshan Nature Reserve in Foping County, 2011-07-14); (b) Takin population (Guanyinshan Nature Reserve in Foping County, 2014-04-29); (c) Wild boar population (Donggou Valley in Foping Nature Reserve, 2015-10-29); (d) Golden monkey population (Cungou Valley in Guanyinshan Nature Reserve in Foping County, 2014-12-03); (e) Family of black bear (Donggou Valley in Foping County, 2013-10-01); (f) Mother and cub of black bear (Yuewangou Valley in Foping County, 2014-09-18) 
野猪和3个小崽)、金丝猴(Rhinopithecus roxellana) 群的个体数(图3d)、黑熊 (Ursus thibetanus) 个体数和 母子情况(图3e，f)等。通过对长期监测获得的照片 数据进行这方面的信息挖掘可以对比不同年份的 种群繁殖和发展情况, 并监测和预测种群数量的变
化，为野生动物保护及管理服务提供支撑。

2.7 野生动物疾病情况监测

野生动物疾病也可以通过红外相机监测获得 信息，如羚牛的肿瘤病和斑羚 (Naemorhedus caudatus)的皮肤病(脱毛) (图4)。在2000-2012年第4次
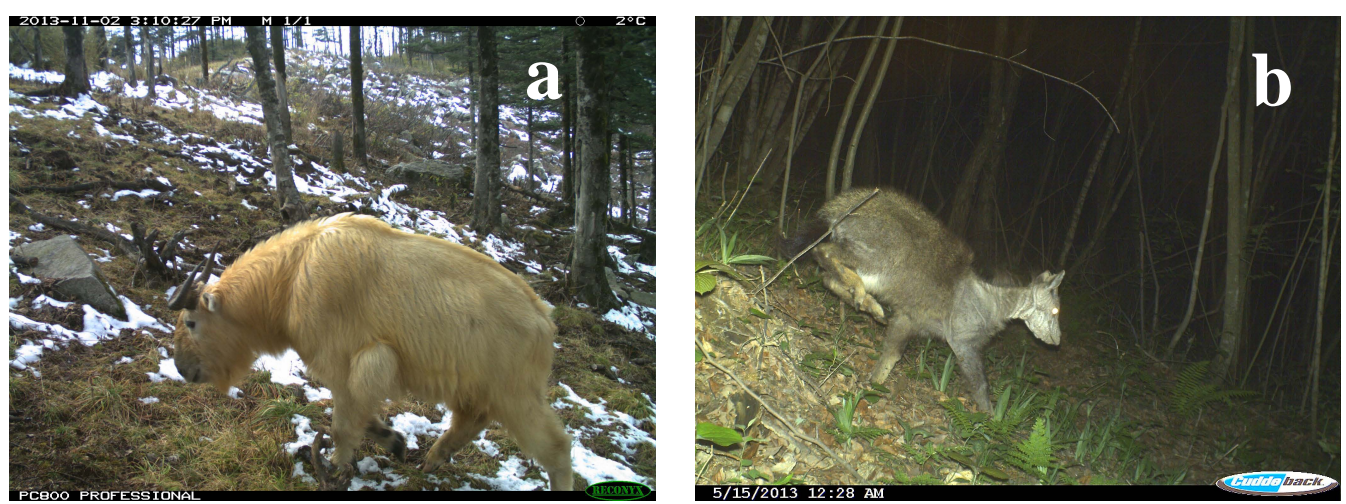

图4 红外相机照片拍到的野生动物疾病(清华大学刘雪华提供照片)。(a)腿部长肿瘤的羚牛(2013-11-02佛坪光头山); (b)因皮 癣脱毛的斑羚(2013-05-15佛坪观音山)

Fig. 4 Disease captured by camera in wild animals. Photos are provided by Xuehua Liu from Tsinghua University. (a) Takin with a tumor in the leg (Guangtoushan Mountain in Foping County, 2013-11-02); (b) Hair loss of goral caused from psoriasis (Guanyinshan Nature Reserve in Foping County, 2013-05-15)
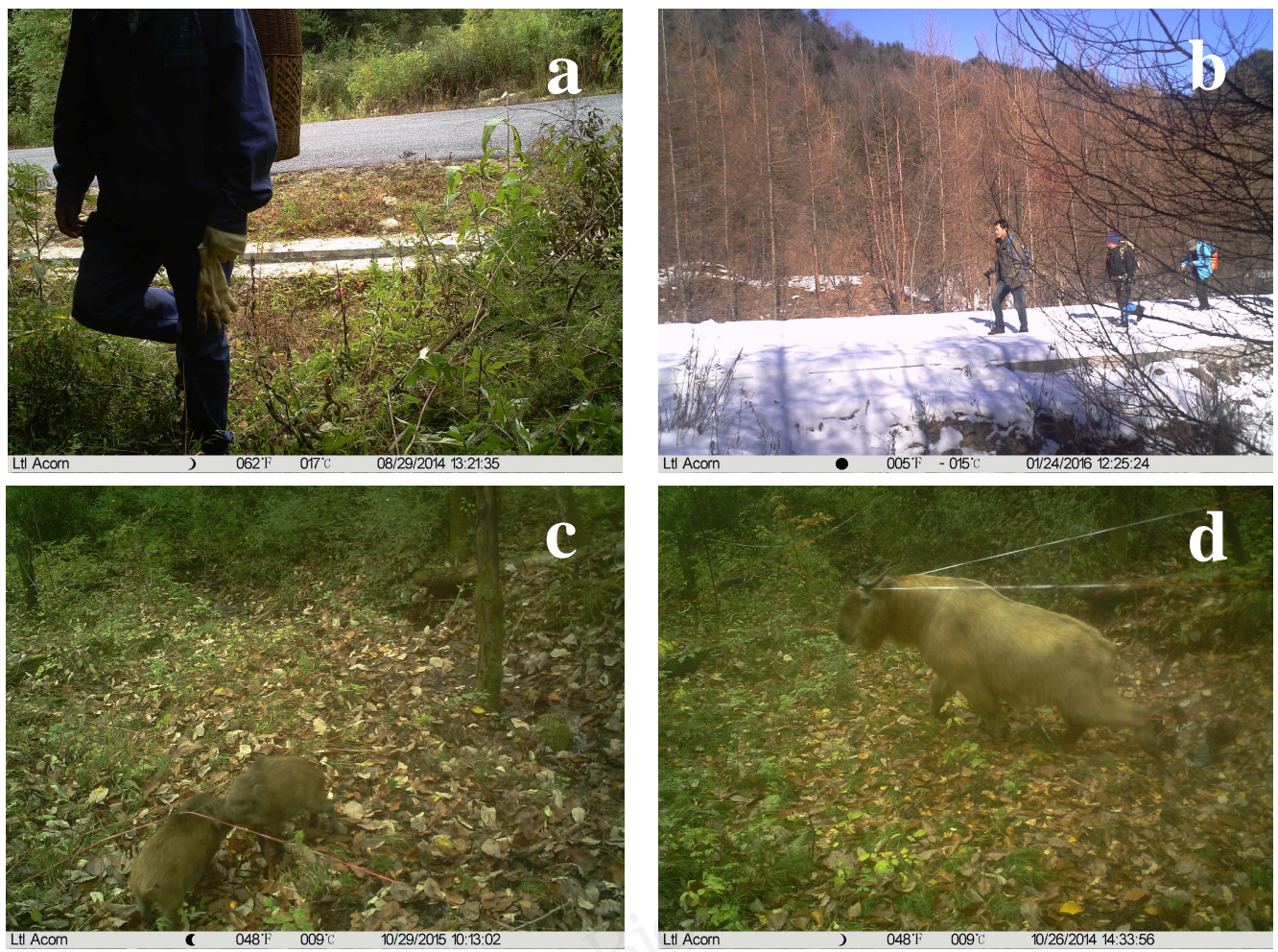

图5 人为活动对野生动物的干扰(清华大学刘雪华提供照片)。(a)道路和采药影响(2014-08-29佛坪观音山); (b)道路和旅游影 响(2016-01-24佛坪观音山); (c)样绳对小野猪的影响(2015-10-29佛坪东沟); (d)样绳对羚牛的影响(2014-10-26佛坪东沟)

Fig. 5 The influence of human activities on wild animals. Photos are provided by Xuehua Liu from Tsinghua University. (a) Effects of roads and Chinese medicine collecting (Guanyinshan Nature Reserve in Foping County, 2014-08-29); (b) Effects of roads and travel (Guanyinshan Nature Reserve in Foping County, 2016-01-24); (c) Effect on little wild boar by sampling rope (Donggou Valley in Foping County, 2015-10-29); (d) Effect on takin by sampling rope (Donggou Valley in Foping County, 2014-10-26) 
大熊猫普查期间，曾发现大量的斑羚尸体，均为皮 肤病大面积发生而导致的死亡。通过早发现可以做 到早预防。

\section{8 人为活动干扰信息提取}

监测中发现, 在保护区也仍然存在各种人类活 动, 如采药、道路、旅游、砍柴、山货采集等, 这 些活动都在不同程度上影响着野生动物。清华大学 研究团队已在陕西观音山自然保护区开展道路影 响监测4年，初步分析发现距离道路最近的红外相 机拍摄到更多的人为活动, 而远离道路的红外相机 能拍摄到更多的野生动物(图5a，b)。科学调查中使 用并留在野外的塑料样绳对动物穿越及行走产生 了很大影响, 如玩要中的小野猪被样绳阻挡, 羚牛 的角被样绳勾住(图5c，d), 这些提示我们野外研究 方法在设计上还有待改进。

\section{3 结论与展望}

生物多样性保护是一个长期的、系统的工程, 需要政府、科研院所、保护区等机构, 甚至每一位 公民的共同参与。红外相机的应用能够大大地节省 人力、物力, 并且能够有效地对一些稀有类群、夜 行性类群进行监测。当前, 在政府和一些国际组织 (如WWF)的支持下, 各保护区都已经开始利用红外 相机进行日常的监测, 积累了大量的数据。对于保 护区工作人员来说，红外数据能干什么、怎么用等 问题，实际上并不是很清楚。

随着红外相机的推广应用, 我们面临的不仅仅 物种编目调查这一基本问题, 而是对监测数据的综 合运用，既包括与环境因子的关系拓展，也涉及区 域间、甚至全国全球监测数据间的纵深比较。从照 片中, 我们不仅可以获取到物种信息, 还可以得到 其他辅助信息, 如数量、行为、疾病、活动情况、 繁殖信息及人为干扰等; 目前我们可获取的环境因 子包括温度和月相, 二者都在一定程度上影响了动 物的行为活动和分布格局。伴随着红外相机的优化 升级, 其他环境因子如光照强度、雨量、风速、风 向等都可以获取, 而对这些环境因子与动物行为、 繁殖、活动间的关系, 尤其是对一些偶见物种、珍 稀物种的深入研究, 能够为物种保护提供最直接的 数据支持。

针对监测数据一体化的问题, 已经有一些监测 网络在成功地运行, 但还远远不够。一方面, 监测
方案不统一造成了数据区域间的差异。但是考虑到 各研究主体(科研院所、保护区)在人员、经费等方 面的差异，目前在全国范围内推行统一方案似乎不 太容易。我们认为，应该继续加大政府扶持力度, 以解决研究主体经费的问题; 开展人员培训, 提高 监测队伍素质。另外，监测数据的共享问题直接制 约了研究主体向监测网络上传数据的积极性。红外 相机的研究单位和人员远不止Camera Data系统内 所包含的单位和人员，还广泛存在于不同高校、科 研机构及各种类型保护区，规范化的数据管理是必 要的。如何在平等互信的原则下，建立切实可行的 数据共享机制, 是实现监测数据一体化进程中不容 忽视的问题。

综上所述，红外相机技术自 20 世纪 20 年代开始 被用于物种监测，在物种多样性、活动格局、种群 参数估计等方面学者们做了许多工作，但对于深层 次的信息提取、数据集成，或者大尺度的比较研究， 还缺乏探索。该技术确实是监测野生动物的一项非 常有效的方法, 帮助我们采集大量数据, 包括一些 野外通常难以采集到的相关信息，以实现对不同生 态系统中的生物多样性进行监测、保护的目的。

\section{参考文献}

Bao XX, Liu BW (2018) Avian and mammalian biodiversity of Heilongjiang Liangshui and Fenglin Reserve. Acta Ecologica Sinica, 38, 502-510. (in Chinese with English abstract) [包欣欣, 刘丙万 (2018) 黑龙江凉水和丰林保护 区鸟类和兽类多样性. 生态学报, 38, 502-510.]

Cai YS, Gong YN, Lu XL, Xiao ZS, Wang XC (2016) Camera trap survey of mammal diversity in Nanling Forests. Ecological Science, 35, 57-61. (in Chinese with English abstract) [蔡玉生, 龚粤宁, 卢学理, 肖治术, 王新财 (2016) 南岭森林哺乳动物多样性的红外相机监测. 生态科学, 35, 57-61.]

Carthew SM, Slater E (1991) Monitoring animal activity with automated photography. The Journal of Wildlife Management, 55, 689-692.

Champion FW (1927) With a Camera in Tiger Land. Chatto \& Windus, London.

Harris PJ (1995) The role of trap cameras in catch per unit effort calculations for species of the South Atlantic bight snapper-grouper complex. Fisheries Research, 22, 1-9.

He BS, Yuan CH, Zhang XM, Li XZ, Li J (2009) Infrared triggered camera-trap survey technique for panda monitoring. Science Journal of Northwest University Online, 7, 32-36. (in Chinese with English abstract) [何佰锁, 袁朝晖, 张希 明, 李小枝, 李健 (2009) 红外线触发数码相机陷阱技术 
在大熊猫监测中的应用. 西北大学学报(自然科学网络 版), 7, 32-36.]

Heilbrun RD, Silvy NJ, Tewes ME, Peterson MJ (2003) Using automatically triggered cameras to individually identify bobcats. Wildlife Society Bulletin, 31, 748-755.

Hiby L, Lovell P, Patil N, Kumar NS, Gopalaswamy AM, Karanth KU (2009) A tiger cannot change its stripes: Using a three-dimensional model to match images of living tigers and tiger skins. Biology Letters, 5, 383-386.

Hu L, Xie WH, Shang T, Jiang BK, Xiao ZS (2016) Preliminary survey for mammal and bird diversity using camera traps in the Longxi-Hongkou National Nature Reserve of Sichuan Province, Southwest China. Acta Theriologica Sinica, 36, 330-337. (in Chinese with English abstract) [胡 力, 谢文华, 尚涛, 姜丙坤, 肖治术 (2016) 龙溪-虹口国 家级自然保护区兽类和鸟类多样性红外相机调查结果初 报. 兽类学报, 36, 330-337.]

Huang XY, Hu DF, Liu WS, Muntifering J (2003) Field survey on South China tigers and their habitat evaluation in Yihuang Provincial Reserve in Jiangxi Province. Journal of Beijing Forestry University, 25, 54-58. (in Chinese with English abstract) [黄祥云, 胡德夫, 刘伟石, Jeff Muntifering (2003) 宜黄自然保护区华南虎野生种群调查及栖息 地评价. 北京林业大学学报, 25, 54-58.]

Huang XY, Hu DF, Tang XP, Wang ZC, Liu WS (2004) Field survey of South China tigers and their habitat evaluation in Hupingshan National Reserve. Journal of Zhejiang Forestry College, 21, 180-184. (in Chinese with English abstract) [黄 祥云, 胡德夫, 唐小平, 王志臣, 刘伟石 (2004) 壸瓶山 自然保护区华南虎野外调查及栖息地评价. 浙江林学院 学报, 21, 180-184.]

Jia XD, Liu XH, Yang XZ, Wu PF, Songer M, Cai Q, He XB, Zhu Y (2014) Seasonal activity patterns of ungulates in Qinling Mountains based on camera-trap data. Biodiversity Science, 22, 737-745. (in Chinese with English abstract) [贾 晓东, 刘雪华, 杨兴中, 武鹏峰, Melissa Songer, 蔡琼, 何祥博, 朱云 (2014) 利用红外相机技术分析秦岭有蹄 类动物活动节律的季节性差异. 生物多样性, 22, 737-745.]

Karanth KU, Nichols JD (1998) Estimation of tiger densities in India using photographic captures and recaptures. Ecology, 79, 2852-2862.

Karanth KU, Chundawat RS, Nichols JD, Kumar N (2004) Estimation of tiger densities in the tropical dry forests of Panna, Central India, using photographic capture-recapture sampling. Animal Conservation, 7, 285-290.

Li B, Zhang ED, Zhang ZH, Liu Y (2008) Preliminary monitoring of Amur tiger population in Jilin Hunchun National Nature Reserve. Acta Theriologica Sinica, 28, 333-341. (in Chinese with English abstract) [李冰, 张恩迪, 张振华, 刘 宇 (2008) 吉林珲春自然保护区东北虎种群的初步监测. 兽类学报, 28, 333-341.]

Li JQ, Xu HG, Wan YQ, Sun JX, Li S, Cai L (2018) Progress in construction of China Mammal Diversity Observation Network (China BON-Mammals). Journal of Ecology and Rural Environment, 34, 12-19. (in Chinese with English abstract) [李佳琦, 徐海根, 万雅琼, 孙佳欣, 李晟, 蔡蕾 (2018) 全国哺乳动物多样性观测网络 (China BONMammals)建设进展. 生态与农村环境学报, 34, 12-19.]

Li Q, Wu JG, Kou XJ, Feng LM (2013) Applications of camera trap in wildlife population ecology. Chinese Journal of Applied Ecology, 24, 947-955. (in Chinese with English abstract) [李勤, 邬建国, 寇晓军, 冯利民 (2013) 相机陷阱 在野生动物种群生态学中的应用. 应用生态学报, 24, 947-955.]

Li S, Wang DJ, Gu XD, McShea WJ (2010) Beyond pandas, the need for a standardized monitoring protocol for large mammals in Chinese nature reserves. Biodiversity and Conservation, 19, 3195-3206.

Li S, McShea WJ, Wang DJ, Lu Z, Gu XD (2012) Gauging the impact of management expertise on the distribution of large mammals across protected areas. Diversity and Distributions, 18, 1166-1176.

Li S, Wang DJ, Xiao ZS, Li XH, Wang TM, Feng LM, Wang Y (2014) Camera-trapping in wildlife research and conservation in China: Review and outlook. Biodiversity Science, 22, 685-695. (in Chinese with English abstract) [李晟, 王 大军, 肖治术, 李欣海, 王天明, 冯利民, 王云 (2014) 红外相机技术在我国野生动物研究与保护中的应用与前 景. 生物多样性, 22, 685-695.]

Li ZL, Kang AL, Lang JM, Xue YG, Ren Y, Zhu ZW, Ma JZ, Liu PQ, Jiang GS (2014) On the assessment of big cats and their prey populations based on camera trap data. Biodiversity Science, 22, 725-732. (in Chinese with English abstract) [李治霖, 康䠛黎, 郎建民, 薛延刚, 任毅, 朱志文, 马建章, 刘培琦, 姜广顺 (2014) 探讨基于红外相机技术 对大型猫科动物及其猎物的种群评估方法. 生物多样性, 22, 725-732.]

Li ZX (2004) The Amur tiger occurred in Hunchun again. Chinese Journal of Wildlife, 25, 34. (in Chinese) [李志兴 (2004) 珲春再现东北虎. 野生动物, 25, 34.]

Liu K, He J, Zhang JH, Feng J, Yu Q, Gu CM, Wu HL (2017) Mammal resource status in the mountain forest ecosystems of southern Anhui Province based on camera trap data. Biodiversity Science, 25, 896-903. (in Chinese with English abstract) [刘凯, 贺君, 张继辉, 冯俊, 宇强, 顾长明, 吴 海龙 (2017) 基于红外相机技术的皖南山区森林生态系 统兽类资源现状. 生物多样性, 25, 896-903.]

Liu XB, Wei W, Zheng XG, Zhao KH, He SW, Zhou WL (2017) Activity rhythms of golden pheasant (Chrysolophus pictus) and satyr tragopan (Tragopan temmminckii) revealed by infrared-triggered cameras. Chinese Journal of Zoology, 52, 194-202. (in Chinese with English abstract) [刘小斌, 韦 伟, 郑䈗光, 赵凯辉, 何少文, 周文良 (2017) 红腹锦鸡 和红腹角雉活动节律一一基于红外相机监测数据. 动物 学杂志, 52, 194-202.] 
Liu XH, Wu PF, Cai Q, He XB, Songer M, Zhu Y, Shao XM (2013) Monitoring wildlife abundance and diversity with infra-red camera traps in Guanyinshan Nature Reserve of Shaanxi Province, China. Ecological Indicators, 33, 121-128.

Liu XH, Wu PF, Shao XM, Songer M, Cai Q, He XB, Zhu Y (2017) Diversity and activity patterns of sympatric animals among four types of forest habitat in Guanyinshan Nature Reserve in the Qinling Mountains, China. Environmental Science and Pollution Research, 24, 16465-16477.

Long H, Li QT, Chen YC, Lu J, Zhang YS (2017) Mammal survey in Baimaxueshan based on infra-red camera monitoring. Bulletin of Biology, 52(4), 6-8. (in Chinese) [龙华, 李庆涛, 陈永春, 陆斤, 张永生 (2017) 基于红外相机监 测的白马雪山哺乳动物资源调查. 生物学通报, 52(4), 6-8.]

Lu XL, Jiang ZG, Tang JR, Wang XJ, Xiang DQ, Zhang JP (2005) Auto-trigger camera traps for studying giant panda and its sympatric wildlife species. Acta Zoologica Sinica, 51, 495-500. (in Chinese with English abstract) [卢学理, 蒋志刚, 唐继荣, 王学杰, 向定乾, 张建平 (2005) 自动 感应照相系统在大熊猫以及同域分布的野生动物研究中 的应用. 动物学报, 51, 495-500.]

Ma KP (2011) Assessing progress of biodiversity conservation with monitoring approach. Biodiversity Science, 19, 125-126. (in Chinese) [马克平 (2011) 监测是评估生物多 样性保护进展的有效途径. 生物多样性, 19, 125-126.]

Ma M, Xu F (2006) Successful camera trapping on snow leopard in the Muzat Valley, Tomur Feng Nature Reserve, Xinjiang, P. R. China. Arid Land Geography, 29, 307-308. (in Chinese) [马鸣, 徐峰 (2006) 利用红外自动照相技术首 次拍摄到清晰雪豹照片——新疆木扎特谷雪豹冬季考察 简报. 干早区地理, 29, 307-308.]

Ma M, Xu F, Chundawat RS, Jumabay K, Wu YQ, Aizezi, Zhu MH (2006) Camera trapping of snow leopards for the photo capture rate and population size in the Muzat Valley of Tianshan Mountains. Acta Zoologica Sinica, 52, 788-793. (in Chinese with English abstract) [马鸣, 徐峰, Chundawat RS, Jumabay Kubanych, 吴逸群, 艾则孜, 朱玛洪 (2006) 利用自动照相术获得天山雪豹拍摄率与个体数量. 动物 学报, 52, 788-793.]

Ma SL, Harris RB (1996) Use of remote camera systems to document wildlife species presence in forested areas of Yunnan. Zoological Research, 17, 360, 370. (in Chinese with English abstract) [马世来, Harris RB (1996) 自动感应 照相系统在野生动物调查中的应用. 动物学研究, 17 , 360, 370.]

Martorello DA, Eason TH, Pelton MR (2001) A sighting technique using cameras to estimate population size of black bears. Wildlife Society Bulletin, 29, 560-567.

O'Brien TG, Baillie JEM, Krueger L, Cuke M (2010) The wildlife picture index: Monitoring top trophic levels. Animal Conservation, 6, 131-139.
O’Connell AF, Nichols JD, Karanth KU (2011) Camera Traps in Animal Ecology: Methods and Analyses. Springer, New York.

Pei JQ (1998) Camera trapping systems to record activity patterns of wildlife. Taiwan Forestry Research, 13, 317-324. (in Chinese) [裴家骐 (1998) 利用自动照相设备记录野生 动物活动模式之评估. 台湾林业科学, 13, 317-324.]

Rowcliffe JM, Carbone C (2008) Surveys using camera traps: Are we looking to a brighter future? Animal Conservation, 11, 185-186.

Rowcliffe JM, Carbone C, Jansen PA, Kays R, Kranstauber B (2011) Quantifying the sensitivity of camera traps: An adapted distance sampling approach. Methods in Ecology and Evolution, 2, 464-476.

Rowcliffe JM, Kays R, Kranstauber B, Carbone C, Jansen PA (2014) Quantifying levels of animal activity using camera trap data. Methods in Ecology and Evolution, 5, 1170-1179.

Rowcliffe JM (2017) Key frontiers in camera trapping research. Remote Sensing in Ecology and Conservation, 3, 107-108.

Royle JA, Nichols JD, Karanth KU, Gopalaswamy AM (2009) A hierarchical model for estimating density in camera-trap studies. Journal of Applied Ecology, 46, 118-127.

Shi XG, Hu Q, Li JQ, Tang Z, Yang J, Li WJ, Shen XL, Li S (2017) Camera-trapping surveys of the mammal and bird diversity in Wolong National Nature Reserve, Sichuan Province. Biodiversity Science, 25, 1131-1136. (in Chinese with English abstract) [施小刚, 胡强, 李佳琦, 唐卓, 杨 建, 李文静, 申小莉, 李晟 (2017) 利用红外相机调查四 川卧龙国家级自然保护区鸟兽多样性. 生物多样性, 25, 1131-1136.]

Tang Z, Yang J, Liu XH, Wang PY, Li ZY, Liu CS (2017a) Activity pattern of Lophophorus Ihuysii by camera-trapping in Wolong National Nature Reserve, China. Sichuan Journal of Zoology, 36, 582-587. (in Chinese with English abstract) [唐卓，杨建，刘雪华，王鹏彦，李周园，Liu CS (2017a) 利用红外相机研究卧龙国家级自然保护区绿尾虹雉的活 动规律. 四川动物, 36, 582-587.]

Tang Z, Yang J, Liu XH, Wang PY, Li ZY (2017b) Research on snow leopards (Panthera uncia) using camera-trapping in Wolong National Nature Reserve, China. Biodiversity Science, 25, 62-70. (in Chinese with English abstract) [唐卓, 杨建, 刘雪华, 王鹏彦, 李周园 (2017b) 基于红外相机 技术对四川卧龙国家级自然保护区雪豹(Panthera uncia) 的研究. 生物多样性, 25, 62-70.]

Wang CP, Liu XH, Wu PF, Cai Q, Shao XM, Zhu Y, Songer M (2015) Research on behavior and abundance of wild boar (Sus scrofa) via infra-red camera in Guanyinshan Nature Reserve in Qinling Mountains, China. Acta Theriologica Sinica, 35, 147-156. (in Chinese with English abstract) [王 长平, 刘雪华, 武鹏峰, 蔡琼, 邵小明, 朱云, Melissa Songer (2015) 应用红外相机技术研究秦岭观音山自然保 护区内野猪的行为和丰富度. 兽类学报, 35, 147-156.]

Wang TM, Feng LM, Yang HT, Han BY, Zhao YH, Juan L, Lü 
XY, Zou L, Li T, Xiao WH, Mou P, Smith JLD, Ge JP (2017) A science-based approach to guide Amur leopard recovery in China. Biological Conservation, 210, 47-55.

Wu PF, Liu XH, Cai Q, He XB, Songer M, Zhu Y, Shao XM (2012) The application of infra-red camera in mammal research in Guanyinshan Nature Reserve, Shaanxi. Acta Theriologica Sinica, 32, 67-71. (in Chinese with English abstract) [武鹏峰, 刘雪华, 蔡琼, 何祥博, Songer M, 朱 云, 邵小明 (2012) 红外相机技术在陕西观音山自然保 护区兽类监测研究中的应用. 兽类学报, 32, 67-71.]

Xiao ZS (2014) An introduction to wildlife camera trapping monitoring from Chinese Forest Biodiversity Monitoring Network (CForBio). Biodiversity Science, 22, 808-809. (in Chinese) [肖治术 (2014) 我国森林动态监测样地的野生 动物红外相机监测. 生物多样性, 22, 808-809.]

Xiao ZS, Li XH, Wang XZ, Zhou QH, Quan RC, Shen XL, Li S (2014a) Developing camera-trapping protocols for wildlife monitoring in Chinese forests. Biodiversity Science, 22, 704-711. (in Chinese with English abstract) [肖治术, 李欣 海, 王学志, 周岐海, 权锐昌, 申小莉, 李晟 (2014a) 探 讨我国森林野生动物红外相机监测规范. 生物多样性, 22, 704-711.]

Xiao ZS, Wang XZ, Li XH (2014b) An introduction to Camera Data: An online database of wildlife camera trap data. Biodiversity Science, 22, 712-716. (in Chinese with English abstract) [肖治术, 王学志, 李欣海 (2014b) 野生动物多 样性监测图像数据管理系统Camera Data介绍. 生物多样 性, 22, 712-716.]

Xiao ZS (2016) Wildlife resource inventory using camera-trapping in natural reserves in China. Acta Theriologica Sinica, 36, 270-271. (in Chinese) [肖治术 (2016) 红外相 机技术促进我国自然保护区野生动物资源编目调查. 兽 类学报, 36, 270-271.]

Xiao ZS, Li XY, Xiang ZF, Li M, Jiang XL, Zhang LB (2017) Overview of the Mammal Diversity Observation Network of Sino BON. Biodiversity Science, 25, 237-245. (in Chinese with English abstract) [肖治术, 李学友, 向左甫, 李明, 蒋
学龙, 张礼标 (2017) 中国兽类多样性监测网的建设规 划与进展. 生物多样性, 25, 237-245.]

Xue MS, Jiang BK, Li WB, Liu XL, Hou WF, Wang PC, Wang S, Nie HX, Zheng H, Bao HZ, Wang SX, Huang XQ, Xiao ZS (2016) Wildlife survey of Taihangshan Macaques National Nature Reserve using camera-trapping in Jiyuan City, Henan Province, China. Acta Theriologica Sinica, 36, 313-321. (in Chinese with English abstract) [薛茂盛, 姜丙 坤, 李伟波, 刘晓良, 侯卫锋, 王朋程, 王帅, 聂怀金金, 郑 贺, 包慧枝, 王淑娴, 黄小群, 肖治术 (2016) 运用红外 相机对太行山狝猴国家级自然保护区(济源)兽类和鸟类 多样性的调查. 兽类学报, 36, 313-321.]

Zhang LB, Cui SP, Huang YJ, Chen DQ, Qiao HJ, Li CW, Jiang ZG (2014) Infra-red camera traps in wildlife research and monitoring in China: Issues and insights. Biodiversity Science, 22, 696-703. (in Chinese with English abstract) [张 履冰, 崔绍朋, 黄元骏, 陈代强, 乔慧捷, 李春旺, 蒋志 刚 (2014) 红外相机技术在我国野生动物监测中的应用: 问题与限制. 生物多样性, 22, 696-703.]

Zhang SS, Zheng FD, Li JQ, Bao QM, Lai JH, Cheng HY (2017) Monitoring diversity of ground-dwelling birds and mammals in Wuyanling National Nature Reserve using infra-red camera traps. Biodiversity Science, 25, 427-429. (in Chinese with English abstract) [章书声, 郑方东, 李佳琦, 包其敏, 赖家厚, 程宏毅 (2017) 基于红外相机技术对乌 岩岭国家级自然保护区地面鸟兽的初步调查. 生物多样 性, 25, 427-429.]

Zhang YS, Jiang WJ, Jiang J, Wang D, Wu JG, Liu FM, Bao WD (2017) Biodiversity monitoring of understory birds and mammals in Beijing Songshan National Nature Reserve. Chinese Journal of Wildlife, 38, 367-375. (in Chinese with English abstract) [张源笙, 蒋万杰, 蒋健, 王丹, 吴记贵, 刘芳茗, 鲍伟东 (2017) 北京松山国家级自然保护区林 下鸟类和兽类多样性动态监测. 野生动物学报, 38, 367-375.]

(责任编委: 蒋学龙 责任编辑: 时意专) 